Check for updates

Cite this: RSC Adv., 2017, 7, 44282

Received 11th August 2017

Accepted 7th September 2017

DOI: $10.1039 / c 7 r a 08874 d$

rsc.li/rsc-advances

\section{Development and application of immobilized surfactant in mass spectrometry-based proteomics $\uparrow$}

\author{
Qiong Wu, (D) ab Fenglong Jiao, ${ }^{\mathrm{b}}$ Fangyuan Gao, ${ }^{\mathrm{b}}$ Chaoshuang Xia, ${ }^{\mathrm{b}}$ Yayao Lv, \\ Qian Yu, ${ }^{b}$ Yangjun Zhang*b and Xiaohong Qian*ab
}

In "bottom-up" proteomics, proteins are first digested into peptides and then characterized by chromatographic separation and mass spectrometry analysis, in which proteolysis has an appreciable influence on the repeatability and reliability of analytical results. To improve recovery and enzymatic efficiency, proteins are often denatured and solubilized with chemical agents such as sodium dodecyl sulphate (SDS), urea (UA), etc. However, surfactant like SDS is difficult to remove from the reacting system and may interfere with protease activity, chromatographic separation of peptides and mass spectrometry analysis. To this end, we have prepared an immobilized surfactant which can preserve the solubilization and denaturation abilities of a surfactant and has the advantage of being easily separated from samples. The denaturation and solubilization capabilities of the newly developed immobilized surfactant were evaluated by comparing the enzymatic hydrolysis efficiencies in the pretreatment of protein samples treated with immobilized surfactant and other common methods. The results showed that the average protein sequence coverage was $42.1 \%$ (digested for $1 \mathrm{~h}$ ), which was $76.89 \%$ higher than that of a control experiment (23.8\%) in the digestion of a standard protein (BSA) and reached the same denaturation ability as that of heating at $95^{\circ} \mathrm{C}$. Moreover, the immobilized surfactant was further tested in the extraction and digestion of the total protein of HeLa cells. The number of identified proteins resulted in similar levels to those exploited with $0.1 \%$ SDS and 8 M UA, both of which are frequently used in lysis buffer, indicating that the immobilized surfactant had a good ability to denature and solubilize proteins. In brief, the immobilized surfactant avoids the shortcomings of UA and SDS and can be utilized in the pretreatment of complex biological samples.

\section{Introduction}

Proteomics is the large-scale study of proteins, particularly their amino acid sequences, post-translational modifications, structures and functions, expressed from a genome, organism, tissue, or cell type. ${ }^{1-3}$ Genes are carriers of genetic information, and proteins are carriers of life activity. The human genome project, which began in the 1990s, has made great advancements. Life science has entered the post-genome era, and the focus has shifted from revealing the genetic information to exposing the laws of life activity at the molecular level, in which proteomics is one of the most important components. ${ }^{4-6}$ The main research strategies of proteomics include "bottom-up", "middle-down"

${ }^{a}$ School of Pharmacy, Guangdong Pharmaceutical University, Guangzhou 510006, Guangdong, China. E-mail: 13911734119@163.com

${ }^{b}$ State Key Laboratory of Proteomics, National Center for Protein Science Beijing, Beijing Institute of Radiation Medicine, Beijing 102206, China. E-mail: 13683167093@163.com

† Electronic supplementary information (ESI) available. See DOI: 10.1039/c7ra08874d and "top-down". ${ }^{7-9}$ In bottom-up proteomics, also called "shotgun" proteomics, ${ }^{\mathbf{1 0}}$ proteins are first digested into peptides, followed by reversed-phase liquid chromatography-tandem mass spectrometry (LC-MS/MS) analysis. The resulting MS data are searched against a protein sequence database for peptide identification; then, the corresponding proteins can be inferred. ${ }^{11-13}$ The "bottom-up" proteomic strategy is widely used in protein expression profiles, post-translational modifications, protein interactions and proteome quantification. ${ }^{14-16}$ However, there are still many difficulties involved when utilizing this strategy, such as obtaining deep coverage, reliability, and repeatability due to the variable physical and chemical properties resulting from differences in amino acid sequences, the varying abundance of different proteins, and the complexity of post-translational modifications, spatial structure and proteinprotein interactions. ${ }^{17,18}$ Therefore, it is necessary to develop new technologies to improve proteomics methods. ${ }^{19-22}$

The pretreatment conditions of protein samples have a significant effect on the composition, chromatographic separation and mass spectrometry analysis of peptide mixtures. ${ }^{23}$ Improving recovery and enzymatic efficiency is of great 
importance for the reproducibility and reliability of proteomic analysis. ${ }^{24}$ Surfactants are commonly used reagents in sample pretreatment and are applied to denature and solubilize proteins, thereby increasing the enzymatic efficiency of the digestion enzymes acting upon the protein sample. Sodium dodecyl sulfate (SDS) is an effective and popularly used surfactant. ${ }^{25,26}$ However, SDS has many disadvantages, including reducing protease activity, thereby affecting enzymatic efficiency, interfering with chromatographic separation and suppressing peptide mass spectrometry signals. Therefore, it often be removed from the system before enzymatic digestion and LC-MS/MS analysis. Conventional sample purification methods, such as precipitation, extraction, ion exchange and dialysis cannot completely remove the SDS in samples, and the removal process can cause an excessive loss of proteins and peptides. New reagents have been utilized to improve the solubilization process, such as sodium deoxycholate (SDC) ${ }^{27}$ and ionic liquids, ${ }^{28}$ which are easier to remove and have better mass spectrometric compatibility. In addition, the filter-aided sample preparation (FASP) method $^{29}$ and desalting columns ${ }^{30}$ are also used for removal of SDS. However, these methods suffer from cumbersome and timeconsuming steps, and need to be further improved.

In recent years, magnetic nanoparticles have been widely used as a new biofunctional material ${ }^{31}$ due to their excellent biocompatibility, low toxicity and large surface area. ${ }^{32,33}$ The easy preparation and rapid magnetic response make magnetic nanoparticles an ideal carrier material for use in fluorescence imaging, drug delivery and proteomic research. ${ }^{34-36}$

In this study, we prepared surface-active surfactant immobilized magnetic nanoparticles that preserve the solubilization and denaturation abilities of a surfactant and have the advantage of easy magnetic separation. Thus, no surfactant remains in the sample during proteolysis, which has no negative effect on protein hydrolysis, chromatographic separation or mass spectrometry analysis.

\section{Materials and methods}

\subsection{Reagents}

Ferric chloride hexahydrate $\left(\mathrm{FeCl}_{3} \cdot 6 \mathrm{H}_{2} \mathrm{O}\right)$, ferrous chloride tetrahydrate $\left(\mathrm{FeCl}_{2} \cdot 4 \mathrm{H}_{2} \mathrm{O}\right)$, trimethoxy (octadecyl) silane (TMOS, technical grade), tetraethyl orthosilicate $\left(\mathrm{Si}\left(\mathrm{OC}_{2} \mathrm{H}_{5}\right)_{4}\right)$, ammonium hydroxide $\left(\mathrm{NH}_{4} \mathrm{OH}\right)$, bovine serum albumin (BSA), urea (UA), Tris-HCl (1 M, pH 8.0), dithiothreitol (DTT), and iodoacetamide (IAA) were purchased from Sigma-Aldrich (St. Louis, MO, USA). Protease inhibitor cocktail tablets were purchased from Roche (Manheim, Germany). Trypsin (from bovine pancreas) was purchased from Promega (Madison, WI, USA). Hydrochloric acid $(\mathrm{HCl})$, ethanol $\left(\mathrm{CH}_{4} \mathrm{O}\right)$ and isopropanol $\left(\mathrm{C}_{3} \mathrm{H}_{8} \mathrm{O}\right)$ were obtained from Sinopharm Chemical Reagent Co., Ltd (Shanghai, China). All other regents were of analytical grade.

\subsection{Syntheses of $\mathrm{Fe}_{3} \mathrm{O}_{4}$ nanoparticles and $\mathrm{Fe}_{3} \mathrm{O}_{4} @ T M O S$ material}

First, $1.46 \mathrm{~g}$ ferric chloride hexahydrate and $0.5 \mathrm{~g}$ ferrous chloride tetrahydrate were dissolved in $6.3 \mathrm{~mL}$ of $0.4 \mathrm{M}$ chlorine.
Next, $62.5 \mathrm{~mL}$ of $0.7 \mathrm{M}$ ammonia was added to a round bottom flask and stirred vigorously. The hydrochloric acid mixture above was added to the round bottom flask rapidly and stirred for $1 \mathrm{~h}$ at room temperature. The precipitation was separated by means of a magnet, washed three times with ethanol and dried under vacuum at $60{ }^{\circ} \mathrm{C}$, by which we obtained ferroferric oxide $\left(\mathrm{Fe}_{3} \mathrm{O}_{4}\right)$ nanoparticles.

Fifty milligrams $\mathrm{Fe}_{3} \mathrm{O}_{4}$ nanoparticles, $22.857 \mathrm{~mL}$ ethanol, $5.714 \mathrm{~mL}$ water and $0.214 \mathrm{~mL}$ ammonia were added together and sonicated for $30 \mathrm{~min}$. The mixture was then transferred to a $100 \mathrm{~mL}$ round bottom flask, and $0.143 \mathrm{~mL}$ tetraethyl orthosilicate was added dropwise and then stirred for $6 \mathrm{~h}$ at room temperature. The precipitate was washed three times with isopropanol.

The resulting material was dispersed in $8.571 \mathrm{~mL}$ isopropanol, $259 \mu \mathrm{L}$ TMOS was added dropwise under $\mathrm{N}_{2}$ atmosphere, and the mixture was stirred for $24 \mathrm{~h}$ at room temperature. The precipitate $\mathrm{Fe}_{3} \mathrm{O}_{4} @$ @MOS, the final product, was washed three times with isopropanol and stored in $3 \mathrm{~mL}$ $\left(\mathrm{Fe}_{3} \mathrm{O}_{4} @\right.$ TMOS with a final concentration of $15 \mathrm{mg} \mathrm{mL}^{-1}$ ) isopropanol.

\subsection{Pretreatment of proteins}

Tryptic digestion of BSA: $1 \mathrm{mg}$ BSA was dissolved in $10 \mathrm{~mL}$ $50 \mathrm{mmol} \mathrm{NH}_{4} \mathrm{HCO}_{3}$, with a final concentration of $0.1 \mu \mathrm{g} \mu \mathrm{L}^{-1}$. Four aliquots of $100 \mu \mathrm{L}$ BSA solution were denatured separately as described in Table S1. $\dagger$ Trypsin was added to the BSA solutions (enzyme to protein weight ratio of $1: 100$ ), and incubated at $37{ }^{\circ} \mathrm{C}$ for $1 \mathrm{~h}$. The solutions were then analysed by MALDITOF mass spectrometry by first depositing $1 \mu \mathrm{L}$ digested peptide solution onto a MALDI plate, followed by $1 \mu \mathrm{L}$ CHCA matrix aqueous solution.

Extraction and trypsin digestion of HeLa proteins: four plates $\left(25 \mathrm{~mm} \times 150 \mathrm{~mm}, 2 \times 10^{7}\right.$ cells per plate) of HeLa cells were separately centrifuged at $500 \times g$ for $3 \mathrm{~min}$ in four different 1.5 mL EP tubes, and the supernatant was discarded. One millilitre of the different lysis buffers, as shown in Table S2, $\dagger$ was added to each of four EP tubes along with protease inhibitor. One hundred micrograms of the resulting protein from each method was then reduced with $10 \mathrm{mM}$ DTT at $56^{\circ} \mathrm{C}$ for $1 \mathrm{~h}$ and alkylated with $50 \mathrm{mM}$ IAA at room temperature in the dark for $1 \mathrm{~h}$. Trypsin was then added to the protein solution at a ratio of 1 : 50 and incubated at $37^{\circ} \mathrm{C}$ for $16 \mathrm{~h}$. The digested peptides of HeLa proteins were desalted using a self-packed C18 desalination column. Of the resulting sample, $1 \mu \mathrm{g}$ peptides from each lysis method were taken for further HPLC-MS/MS analysis.

\subsection{Mass spectrometry analysis}

MALDI-TOF MS analysis: the MALDI-TOF mass analysis was performed on an ultrafleXtreme time-of-flight mass spectrometer (Bruker, Germany) in a positive-ion reflector mode with an available accelerating voltage of $20 \mathrm{kV}$. The nitrogen laser was $337 \mathrm{~nm}$, and the laser energy was $80 \%$. The mass range of the mass spectra was between $\mathrm{m} / \mathrm{z} 700$ and 3500 .

Nano LC-MS/MS analysis: the high-performance liquid chromatograph used was UltiMate 3000 RSLCnano (Thermo 
Fisher Scientific, USA). The chromatographic column was selfpacked $(150 \mu \mathrm{m} \times 12 \mathrm{~cm}$, New Objective, USA) with a particle size of $1.9 \mu \mathrm{m}$ (Dr Maisch Gmbh, Germany). The digested peptide mixture was dissolved with mobile phase A $(0.1 \%$ FA aqueous solution), the loading volume was $5 \mu \mathrm{L}$, and the flow rate was $600 \mathrm{~nL} \mathrm{~min}^{-1}$. A 90 minute gradient was established with mobile phase A and mobile phase B $(0.08 \%$ FA- $80 \%$ ACN aqueous solution). The elution gradient was composed of $0 \mathrm{~min}$ of $5 \% \mathrm{~B}, 0-8 \mathrm{~min}$ of $5 \% \mathrm{~B}-8 \% \mathrm{~B}, 8-24 \mathrm{~min}$ of $8 \% \mathrm{~B}-13 \% \mathrm{~B}, 24-$ $60 \mathrm{~min}$ of $13 \% \mathrm{~B}-28 \% \mathrm{~B}, 60-79 \mathrm{~min}$ of $28 \% \mathrm{~B}-40 \% \mathrm{~B}, 79-80 \mathrm{~min}$ of $40 \%$ B-95\% B, 80-86 min of $95 \%$ B-6\% B, and $86-90$ min of $6 \% \mathrm{~B}$. The eluted peptides were passed through an electrospray ionization source (ESI) directly into the mass spectrometer. The mass spectrometer (Q Exactive HF, Thermo Fisher Scientific, USA) was operated in positive mode with a spray voltage of $2 \mathrm{kV}$. The full MS scan was acquired from $\mathrm{m} / \mathrm{z} 300$ to 4000 with a resolution of 120000 and an MS AGC of 2e6. The MS/MS scan was acquired from $\mathrm{m} / \mathrm{z} 300$ to 1400 with a resolution of 15000 , MS2 AGC of 2e4 and MS2 maximum ion implantation time of 19 ms.

\subsection{Data analysis}

MALDI-TOF spectra were analysed by flexAnanlysis software (version 3.3). Peptide mass fingerprints were searched via Mascot (version 2.3.01, Matrix Science). The Mascot parameters were set as follows: the enzyme was set as trypsin, and two missed cleavages at most were allowed; fixed modification was carbamidomethylation (Cys), and variable modification was methionine oxidation (Met); and the mass tolerance was set as 0.2 Da.

The raw data of MS spectra was searched with Mascot builtin Proteome Discoverer software (version 2.1 SP2, Thermo Scientific). The Mascot parameters were set as follows: the enzyme was set as trypsin, and two missed cleavages at most were allowed; fixed modification was carbamidomethylation (Cys), and variable modification was methionine oxidation (Met); the precursor tolerance was $10 \mathrm{ppm}$; the fragment tolerance was $20 \mathrm{mmu}$; and the false discovery rate (FDR) was set as $1 \%$. The database used was the human protein database (download from http:/www.uniprot.org/uniprot/? query $=$ homo $\% 20$ protein $\&$ fil $=\&$ sort $=$ score on April $\left.18^{\text {th }}, 2017\right)$.

\section{Results and discussion}

\subsection{Preparation and characterization of the immobilized surfactant}

The preparation process of the immobilized surfactant is shown in Scheme 1, in which $\mathrm{Fe}_{3} \mathrm{O}_{4}$ nanoparticles with a diameter of approximately $10 \mathrm{~nm}$ were first prepared and then coated with tetraethyl orthosilicate. Finally, the long carbon chains were fixed by $\mathrm{Si}-\mathrm{O}$ to the surface of the magnetic nanoparticles. The denaturation mechanism of $\mathrm{Fe}_{3} \mathrm{O}_{4}$ @TMOS was similar to that of a surfactant, mainly through the long carbon chains interacting with proteins and other ends interacting with water to denature and solubilize proteins. The large nanoscale hydrophilic core of $\mathrm{Fe}_{3} \mathrm{O}_{4}$ @TMOS remained outside the proteins

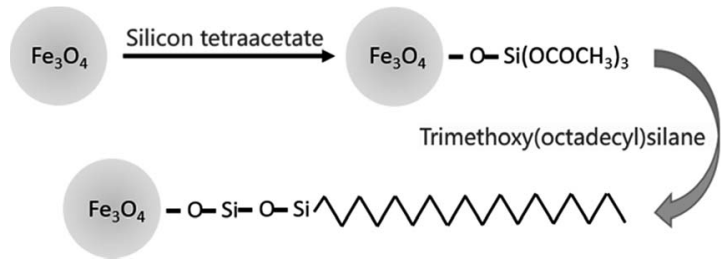

Scheme 1 The preparation process of $\mathrm{Fe}_{3} \mathrm{O}_{4}$ @TMOS.

which was analogous to the hydrophilic side of a surfactant, but unlike the surfactant, $\mathrm{Fe}_{3} \mathrm{O}_{4} @$ @MOS can be easily separated from samples under magnetic filed. The frequently used $\mathrm{Fe}_{3} \mathrm{O}_{4}$ nanoparticles have a larger diameter (approximately $250 \mathrm{~nm}$ ), such as $\mathrm{Fe}_{3} \mathrm{O}_{4}$ nanoparticles prepared by $\mathrm{Hu}$, etal. ${ }^{37}$ which carried immobilized enzymes. As proteins in aqueous solution are usually 5-10 $\mathrm{nm}$ in diameter, $\mathrm{Fe}_{3} \mathrm{O}_{4}$ nanoparticles with larger sizes cannot easily make full contact with proteins. Therefore, a coprecipitation method was used to prepare smaller and more uniform $\mathrm{Fe}_{3} \mathrm{O}_{4}$ nanoparticles. In addition, the magnetic nanoparticles had numerous hydroxyl groups after coating with $\mathrm{SiO}_{2}$ this endows good hydrophilicity for the hydrophilic side. The long carbon chain with hydrophobicity, as the hydrophobic side, can insert into proteins and induce protein denaturation and solubilization.

The morphology of $\mathrm{Fe}_{3} \mathrm{O}_{4}$ and $\mathrm{Fe}_{3} \mathrm{O}_{4}$ @TMOS nanoparticles was characterized by transmission electron microscopy (TEM, FEI, USA). As shown in Fig. 1, the $\mathrm{Fe}_{3} \mathrm{O}_{4}$ nanoparticles have an average diameter of $10 \mathrm{~nm}$. After modification, the edges of the $\mathrm{Fe}_{3} \mathrm{O}_{4} @$ @MOS nanoparticles were obviously blurred, and the size was also marginally increased (Fig. 1e). Since $\mathrm{Fe}_{3} \mathrm{O}_{4} @ \mathrm{TMOS}$ had a magnetic response and a small particle size, there was a tendency for it to agglomerate. However, it can be uniformly dispersed in the solution by ultrasound before use (Fig. 2a).

According to elemental analysis of the $\mathrm{Fe}_{3} \mathrm{O}_{4}$ and $\mathrm{Fe}_{3} \mathrm{O}_{4} @$ TMOS nanoparticles (Table 1), after modification with TMOS, the carbon content increased from $0.81 \%$ to $3.44 \%$, which indicates that TMOS was successfully immobilized on the surface of $\mathrm{Fe}_{3} \mathrm{O}_{4}$ nanoparticles. Fourier transform infrared

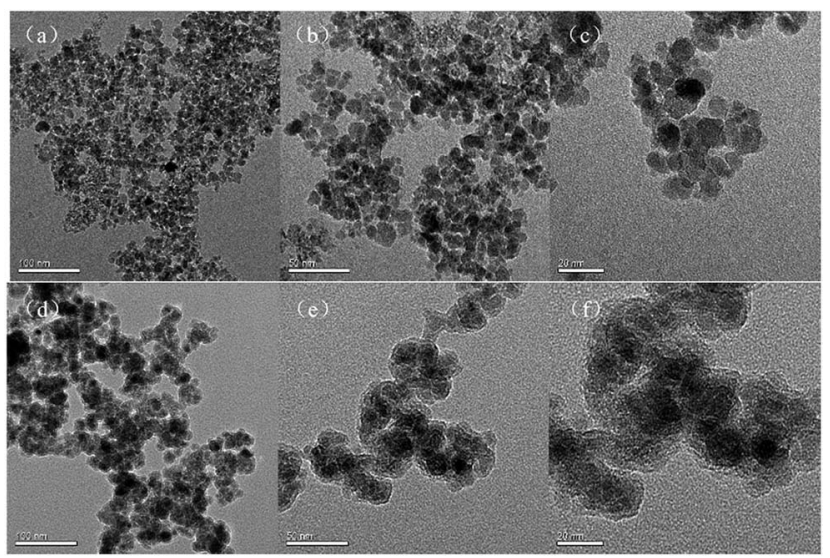

Fig. 1 TEM of $\mathrm{Fe}_{3} \mathrm{O}_{4}$ magnetite nanoparticle $(\mathrm{a}, \mathrm{b}, \mathrm{c})$ and $\mathrm{Fe}_{3} \mathrm{O}_{4} \mathrm{Q}$ $\operatorname{TMOS}(d, e, f)$. 


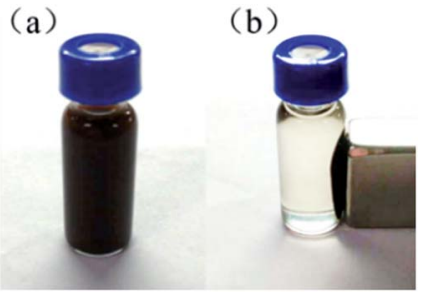

Fig. 2 (a) $\mathrm{Fe}_{3} \mathrm{O}_{4}$ (TTMOS evenly dispersed in isopropanol; (b) the separation of $\mathrm{Fe}_{3} \mathrm{O}_{4}$ @TMOS and the solvent under the action of an applied magnetic field.

Table 1 Elemental analysis of $\mathrm{Fe}_{3} \mathrm{O}_{4}$ and $\mathrm{Fe}_{3} \mathrm{O}_{4}$ aTMOS magnetite nanoparticles

\begin{tabular}{lccccc}
\hline Magnetite nanoparticles & $\mathrm{mg}$ & $\mathrm{N} \%$ & $\mathrm{C} \%$ & $\mathrm{H} \%$ & $\mathrm{~S} \%$ \\
\hline $\mathrm{Fe}_{3} \mathrm{O}_{4}$ & 5.338 & 0.02 & 0.81 & 1.373 & 0.506 \\
$\mathrm{Fe}_{3} \mathrm{O}_{4} @$ TMOS & 5.352 & 0.29 & 3.44 & 1.176 & 0.269
\end{tabular}

spectroscopy (FT-IR, Nicolet, USA) was used to further characterize the chemical constituents of these two types of nanoparticles. As shown in Fig. 3, TMOS showed strong peaks at $2920 \mathrm{~cm}^{-1}$ and $2860 \mathrm{~cm}^{-1}$, which are the absorption peaks of $\mathrm{C}-\mathrm{H}$ stretching vibrations $\left(\sigma_{\mathrm{C}-\mathrm{H}}\right)$. These peaks were not observed in the FT-IR spectra of $\mathrm{Fe}_{3} \mathrm{O}_{4}$ nanoparticles, while after immobilization of TMOS on the surface, these peaks could again be clearly identified. The results suggest that TMOS was successfully immobilized on the surface of the nanoparticles. The amount of TMOS bound to the surface of $\mathrm{Fe}_{3} \mathrm{O}_{4} @$ TMOS was measured by thermogravimetric analysis (TGA, TA instrument, USA). As shown in Fig. 4, the heat loss of $\mathrm{Fe}_{3} \mathrm{O}_{4}$ nanoparticles was approximately $8 \%$, which was due to the volatilization of the crystallization water, consistent with the results of elemental analysis, which showed that $\mathrm{Fe}_{3} \mathrm{O}_{4}$ nanoparticles contained $1.373 \%$ elemental hydrogen. In contrast, the weight loss of $\mathrm{Fe}_{3} \mathrm{O}_{4} @$ @MOS was up to $17 \%$, which was due to the volatilization of crystallization water and carbon chains on the surface of $\mathrm{Fe}_{3} \mathrm{O}_{4} @$ TMOS under high temperature conditions.

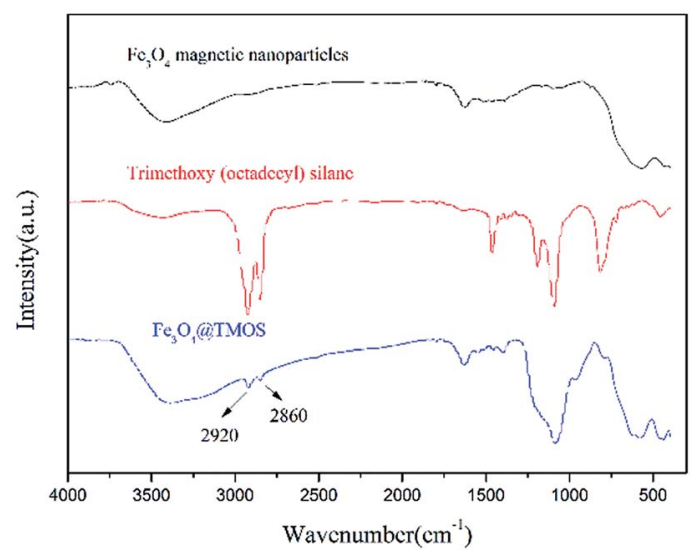

Fig. 3 FT-IR spectra of $\mathrm{Fe}_{3} \mathrm{O}_{4}$ magnetite nanoparticles, trimethoxy(octadecyl)silane and $\mathrm{Fe}_{3} \mathrm{O}_{4}$ (aTMOS.

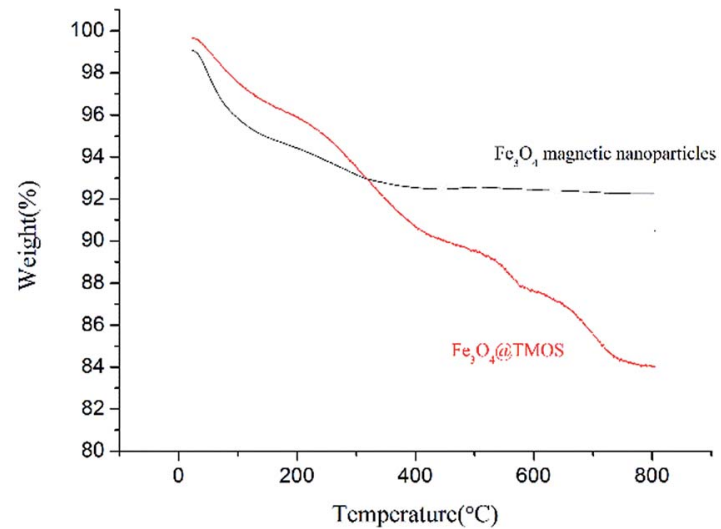

Fig. 4 TGA profiles of $\mathrm{Fe}_{3} \mathrm{O}_{4}$ magnetite nanoparticles and $\mathrm{Fe}_{3} \mathrm{O}_{4}$ @TMOS

The amount of TMOS bound to the surface of $\mathrm{Fe}_{3} \mathrm{O}_{4}$ was found to be $160 \mu \mathrm{g} \mathrm{mg}^{-1}$.

As shown in Fig. $\mathrm{S} 1, \uparrow$ the magnetic field lines are uniformly symmetrical in the magnetic hysteresis loop (Quantum Design, USA), indicating that the prepared $\mathrm{Fe}_{3} \mathrm{O}_{4}$ nanoparticles had superparamagnetism. After modification of the carbon chain, the magnetic properties of $\mathrm{Fe}_{3} \mathrm{O}_{4} @ \mathrm{TMOS}$ were not significantly reduced, indicating that $\mathrm{Fe}_{3} \mathrm{O}_{4} @$ $@$ TMOS had constant magnetic properties and could be easily separated under an applied magnetic field (Fig. 2a and b).

\subsection{Protein denaturation ability of the immobilized surfactant on standard protein BSA}

SDS is difficult to be removed from samples and interferes with the ionization behaviour of peptides when analysed by mass spectrometry. Fig. 5 shows that the MALDI-TOF mass spectra of standard protein BSA digests cleaved by trypsin for $1 \mathrm{~h}$ under the following conditions: (Fig. 5a) undenatured, (Fig. 5b) denatured with SDS followed by removal of SDS using the FASP method, (Fig. 5c) denatured with SDS without SDS removal, (Fig. 5d) denatured at $95{ }^{\circ} \mathrm{C}$ and (Fig. 5e) denatured with $\mathrm{Fe}_{3^{-}}$ $\mathrm{O}_{4} @$ @TMOS. Compared with Fig. 5a, the normal peptide peaks were absent and a large number of impurity peaks were apparent in the sample denatured with SDS (Fig. 5c). The result indicated that SDS had a considerable interference with mass spectrometry analysis and could not be removed by the conventional FASP method (Fig. 5b). Thermal denaturation, a frequently used denaturation method (also a completely denatured method), (Fig. 5d), showed that the number of peptide peaks increased compared with undenatured sample (Fig. 5a). Using the $\mathrm{Fe}_{3} \mathrm{O}_{4} @$ @MOS denaturation method, the number of peptide peaks was significantly increased, and no impurity peaks appeared (Fig. 5d). The results indicate that $\mathrm{Fe}_{3} \mathrm{O}_{4} @$ @TMOS can denature BSA effectively and can be completely separated by an external magnetic field and these nanoparticles do not interfere with the mass spectrometry analysis.

The amino acid sequence coverages of BSA digested under different denaturing conditions were examined. As shown in 



Fig. 5 MALDI-TOFMS spectra of BSA digests (1 h) under conditions of undenatured (a), denatured with SDS followed by SDS removal (b), denatured with SDS without removal (c), denatured with $95^{\circ} \mathrm{C}$ (d) and denatured with $\mathrm{Fe}_{3} \mathrm{O}_{4}$ (aTMOS (e).

Table S3-S5 $\dagger$ and Fig. S2-S4, $\uparrow$ the $41 \%$ amino acid sequence coverage of BSA digestion after denaturing by calefaction at $95{ }^{\circ} \mathrm{C}$ indicated that the BSA was completely denatured. Coverage had been greatly improved compared to the results of undenatured BSA of $23.8 \%$. In addition, no peptides can be identified in BSA digests denatured by SDS because of the interference by SDS in mass spectrometry analysis. As shown in Fig. 6, the average amino acid sequence coverage of BSA digested after denaturation by $\mathrm{Fe}_{3} \mathrm{O}_{4} @ T M O S$ for three times was $42.1 \%$, which was much higher than that of the undenatured BSA digest (increased by 76.89\%) and reached the same enzymatic efficiency of calefaction at $95{ }^{\circ} \mathrm{C}$ (Fig. 6). Therefore, $\mathrm{Fe}_{3} \mathrm{O}_{4} @ T M O S$ can denature BSA completely, indicating that $\mathrm{Fe}_{3} \mathrm{O}_{4} @ T M O S$ has a substantial ability to denature protein.

\subsection{Examination of protein denaturation and solubilization abilities of the immobilized surfactant using a complex sample}

To further examine the protein extraction, denaturation and solubilization performance of the immobilized surfactant, a complex sample, HeLa cells, was processed with the immobilized surfactant and compared with extraction by $\mathrm{H}_{2} \mathrm{O}, 0.1 \%$ SDS and 8 M UA (Table 2).

The ability of $\mathrm{Fe}_{3} \mathrm{O}_{4}$ @TMOS to extract proteins from a complex sample was demonstrated by comparing the results to those of using $\mathrm{H}_{2} \mathrm{O}$ alone, which is a pollution and interference free method. The number of identified proteins increased by $35.05 \%$ using $\mathrm{Fe}_{3} \mathrm{O}_{4}$ @TMOS, compared to the number of proteins identified when using $\mathrm{H}_{2} \mathrm{O}$ alone as a lysis reagent.

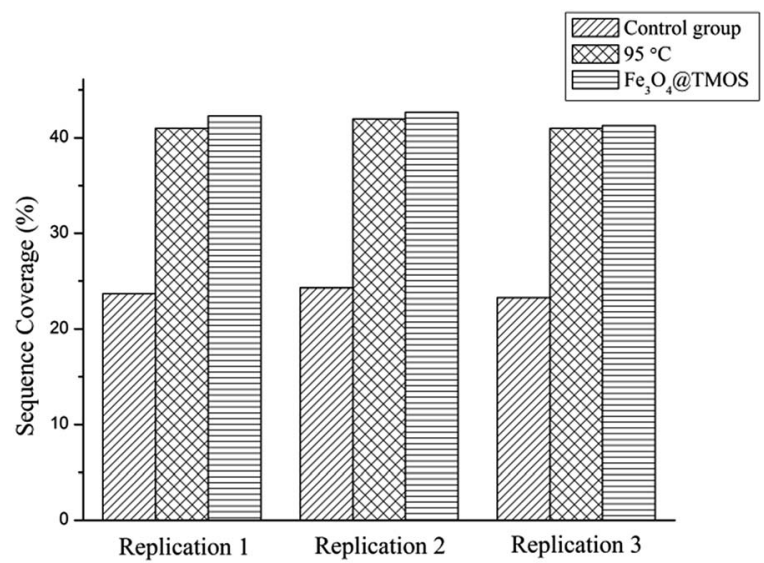

Fig. 6 Sequence coverages of BSA identified by mass spectrometry for three times (control group: undenatured BSA digested for $1 \mathrm{~h}$; $95^{\circ} \mathrm{C}$ : BSA digested for $1 \mathrm{~h}$ after denatured with $95^{\circ} \mathrm{C}$; $\mathrm{Fe}_{3} \mathrm{O}_{4} @$ @TMOS: $\mathrm{BSA}$ digested for $1 \mathrm{~h}$ after denatured with $\mathrm{Fe}_{3} \mathrm{O}_{4} \mathrm{QTMOS}$ ).

Table 2 Numbers of HeLa peptides and proteins extracted and identified by mass spectrometer

\begin{tabular}{|c|c|c|}
\hline Lysis reagents & Peptide number & Protein number \\
\hline $\mathrm{Fe}_{3} \mathrm{O}_{4} @ \mathrm{TMOS}$ & 27388 & 3668 \\
\hline $\mathrm{H}_{2} \mathrm{O}$ & 12688 & 2716 \\
\hline $0.1 \%$ SDS & 24136 & 3547 \\
\hline $4 \%$ SDS & 17415 & 2934 \\
\hline $8 \mathrm{M}$ UA & 24151 & 3671 \\
\hline
\end{tabular}


A frequently used lysis buffer, $0.1 \% \mathrm{SDS}^{38}$ has a robust ability to solubilize and denature membrane proteins. Compared with this reagent, $\mathrm{Fe}_{3} \mathrm{O}_{4} @$ TMOS extracted slightly more proteins. However, SDS is hard to remove ${ }^{39}$ and interferes with subsequent protein analysis by MS. ${ }^{40}$ When the concentration of SDS was increased to $4 \%$ followed by FASP purification, a large number of proteins were lost, and the number of identified proteins by MS decreased to 2934. It is interesting to note that $\mathrm{Fe}_{3} \mathrm{O}_{4} @$ $@ M O S$ can effectively avoid this problem because of its easy removal by a magnet (Fig. 2); thus, there is no impact on MS analysis.

Another widely used lysis buffer is $8 \mathrm{M} \mathrm{UA}^{\mathbf{1 3 , 2 6}}$ which is highly efficient at denaturing and solubilizing proteins by decreasing the hydrophobic effect and directly binding to proteins via hydrogen bonds. ${ }^{41-43}$ The number of proteins extracted from HeLa cells with $\mathrm{Fe}_{3} \mathrm{O}_{4} @$ TMOS and identified by MS was nearly the same as the number extracted using $8 \mathrm{M} \mathrm{UA}$, which is regarded as a good cell lysate reagent. UA has shortcomings, however, including poor thermal stability and a high salt concentration, thus, it cannot be heated, or else protein amidation can occur, and it must be diluted to less than $2 \mathrm{M}$ before enzymatic hydrolysis. In contrast, the samples can be heated to shorten the reaction time when $\mathrm{Fe}_{3} \mathrm{O}_{4} @$ @MOS is used, and it can be easily removed to avoid enzyme deactivation in the next processing step.

Three replicated experiments were performed (Fig. S5-S7†) and a total of 5092 proteins extracted by $\mathrm{Fe}_{3} \mathrm{O}_{4}$ @TMOS were identified. In all the above results indicated that $\mathrm{Fe}_{3} \mathrm{O}_{4} @ \mathrm{TMOS}$ is comparable to SDS and UA when used for protein lysis, but unlike these commonly used reagents, $\mathrm{Fe}_{3} \mathrm{O}_{4} @$ @MOS can be heated and then be removed by a magnet to shorten the reaction time, simplify the experimental steps and reduce sample loss, no negative impact on mass spectrometry analysis. These suggest that $\mathrm{Fe}_{3} \mathrm{O}_{4} @$ TMOS has a strong ability to denature and solubilize proteins and can be used in future proteomics studies.

\section{Conclusions}

An immobilized surfactant was prepared by modifying the long carbon chain on the surface of magnetic nanoparticles. The sample solution and the immobilized surfactant can be easily separated by applying an external magnetic field before digestion or LC-MS/MS analysis procedures. This avoids interference from surfactants, which are often difficult to be removed in conventional experiments in downstream MS analysis of proteins. The protein denaturation and solubilization abilities of synthesized $\mathrm{Fe}_{3} \mathrm{O}_{4} @$ @MOS were verified with BSA and protein extraction of HeLa cells. The experimental results showed that the average amino acid sequence coverage was $42.1 \%$ for BSA denatured by immobilized surfactant, which increased by $76.89 \%$ compared with that of the undenatured BSA digest. Additionally, $\mathrm{Fe}_{3} \mathrm{O}_{4} @$ TMOS achieved the same denaturation level as that of the calefaction method. When using immobilized surfactant to extract and denature HeLa proteins, the number of proteins subsequently identified by MS was comparable with that of $8 \mathrm{M}$ UA and $0.1 \%$ SDS. These results demonstrate that immobilized surfactant has a good ability to denature and solubilize proteins, avoids the shortcomings of both UA and SDS, and can be utilized in the pretreatment of biological samples for analysis by MS.

\section{Conflicts of Interest}

The authors declared no conflict of interest.

\section{Acknowledgements}

This work was supported by National Key R\&D Program of China (2017YFA0505002), the National Key Program for Basic Research of China (2013CB911204 and 2016YFA0501403), the National Key Program for Scientific Instrument and Equipment Development (2012YQ12004407 and 2013YQ14040506).

\section{Notes and references}

1 A. Pandey and M. Mann, Nature, 2000, 405, 837.

2 S. Chen and A. C. Harmon, Proteomics, 2006, 6, 5504-5516.

3 S. P. Gygi, Y. Rochon, B. R. Franza and R. Aebersold, Mol. Cell. Biol., 1999, 19, 1720-1730.

4 M. R. Wilkins, J.-C. Sanchez, A. A. Gooley, R. D. Appel, I. Humphery-Smith, D. F. Hochstrasser and K. L. Williams, Biotechnol. Genet. Eng. Rev., 1996, 13, 19-50.

5 M. R. Wilkins, R. D. Appel, J. E. Van Eyk, M. Chung, A. Görg, M. Hecker, L. A. Huber, H. Langen, A. J. Link and Y. K. Paik, Proteomics, 2006, 6, 4-8.

6 V. C. Wasinger, S. J. Cordwell, A. Cerpa-Poljak, J. X. Yan, A. A. Gooley, M. R. Wilkins, M. W. Duncan, R. Harris, K. L. Williams and I. Humphery-Smith, Electrophoresis, 1995, 16, 1090-1094.

7 C. May, F. Brosseron, P. Chartowski, C. Schumbrutzki, B. Schoenebeck and K. Marcus, Data Mining in Proteomics: From Standards to Applications, 2011, pp. 3-26.

8 M. Wilhelm, J. Schlegl, H. Hahne, A. M. Gholami, M. Lieberenz, M. M. Savitski, E. Ziegler, L. Butzmann, S. Gessulat and H. Marx, Nature, 2014, 509, 582-587.

9 K. Nakata, T. Ichibangase, R. Saitoh, M. Ishigai and K. Imai, Analyst, 2015, 140, 71-73.

10 Y. Zhang, B. R. Fonslow, B. Shan, M.-C. Baek and J. R. Yates III, Chem. Rev., 2013, 113, 2343-2394.

11 A. Armirotti, Curr. Anal. Chem., 2009, 5, 116-130.

12 J. M. Chick, D. Kolippakkam, D. P. Nusinow, B. Zhai, R. Rad, E. L. Huttlin and S. P. Gygi, Nat. Biotechnol., 2015, 33, 743749.

13 A. Schmudlach, J. Felton, C. Cipolla, L. Sun, R. T. Kennedy and N. J. Dovichi, Analyst, 2016, 141, 1700-1706.

14 J. Mayne, Z. Ning, X. Zhang, A. E. Starr, R. Chen, S. Deeke, C.-K. Chiang, B. Xu, M. Wen and K. Cheng, Anal. Chem., 2015, 88, 95-121.

15 C. Evans, J. Noirel, S. Y. Ow, M. Salim, A. G. Pereira-Medrano, N. Couto, J. Pandhal, D. Smith, T. K. Pham and E. Karunakaran, Anal. Bioanal. Chem., 2012, 404, 1011-1027. 16 T. H. Steinberg, B. J. Agnew, K. R. Gee, W. Y. Leung, T. Goodman, B. Schulenberg, J. Hendrickson, 
J. M. Beechem, R. P. Haugland and W. F. Patton, Proteomics, 2003, 3, 1128-1144.

17 A. Politis, F. Stengel, Z. Hall, H. Hernández, A. Leitner, T. Walzthoeni, C. V. Robinson and R. Aebersold, Nat. Methods, 2014, 11, 403-406.

18 A. H. Smits and M. Vermeulen, Trends Biotechnol., 2016, 34, 825-834.

19 Q. Qi, G. Yan, C. Deng and X. Zhang, Anal. Bioanal. Chem., 2016, 408, 8437-8445.

20 M. des Plantes, C. ProtØines, F. Mauguio and D. Pathologique, Electrophoresis, 2000, 21, 3329-3344.

21 L. Zhang, J. Xie, X. e. Wang, X. Liu, X. Tang, R. Cao, W. Hu, S. Nie, C. Fan and S. Liang, Proteomics, 2005, 5, 4510-4524.

22 F. Jiao, R. Zhai, J. Huang, Y. Zhang, Y. Zhang and X. Qian, $R S C A d v .$, 2016, 6, 84113-84118.

23 A. Shevchenko, H. Tomas, J. Havlis, J. V. Olsen and M. Mann, Nat. Protoc., 2007, 1, 2856-2860.

24 G. Menschaert, W. Van Criekinge, T. Notelaers, A. Koch, J. Crappé, K. Gevaert and P. Van Damme, Mol. Cell. Proteomics, 2013, 12, 1780-1790.

25 D. Botelho, M. J. Wall, D. B. Vieira, S. Fitzsimmons, F. Liu and A. Doucette, J. Proteome Res., 2010, 9, 2863-2870.

26 J. R. Wisniewski, A. Zougman, N. Nagaraj and M. Mann, Nat. Methods, 2009, 6, 359.

27 A. Serra, H. Zhu, X. Gallart-Palau, J. E. Park, H. H. Ho, J. P. Tam and S. K. Sze, Anal. Bioanal. Chem., 2016, 408, 1963-1973.

28 Z. Sui, Y. Weng, Q. Zhao, N. Deng, F. Fang, X. Zhu, Y. Shan, L. Zhang and Y. Zhang, Talanta, 2016, 161, 541-546.

29 A. J. Nel, S. Garnett, J. M. Blackburn and N. C. Soares, J. Proteome Res., 2015, 14, 1637-1642.
30 A. Zienkiewicz, J. D. Rejón, J. de Dios Alché, M. I. RodríguezGarcía and A. J. Castro, Plant Proteomics: Methods and Protocols, 2014, pp. 85-91.

31 Q. A. Pankhurst, J. Connolly, S. K. Jones and J. Dobson, J. Phys. D: Appl. Phys., 2003, 36, R167.

32 A. H. Lu, E. e. L. Salabas and F. Schüth, Angew. Chem., Int. Ed., 2007, 46, 1222-1244.

$33 \mathrm{H}$. Teymourian, A. Salimi and S. Khezrian, Biosens. Bioelectron., 2013, 49, 1-8.

34 Y. Zhang, G.-M. Zeng, L. Tang, D.-L. Huang, X.-Y. Jiang and Y.-N. Chen, Biosens. Bioelectron., 2007, 22, 2121-2126.

35 Q. Pankhurst, N. Thanh, S. Jones and J. Dobson, J. Phys. D: Appl. Phys., 2009, 42, 224001.

36 R. Zhai, F. Jiao, D. Feng, F. Hao, J. Li, N. Li, H. Yan, H. Wang, Z. Jin and Y. Zhang, Electrophoresis, 2014, 35, 3470-3478.

37 Z. Hu, L. Zhao, H. Zhang, Y. Zhang, R. a. Wu and H. Zou, J. Chromatogr. A, 2014, 1334, 55-63.

38 M. A. K. Markwell, S. M. Haas, L. Bieber and N. Tolbert, Anal. Biochem., 1978, 87, 206-210.

39 L. Henderson, S. Oroszlan and W. Konigsberg, Anal. Biochem., 1979, 93, 153-157.

40 R. Pitt-Rivers and F. A. Impiombato, Biochem. J., 1968, 109, 825-830.

41 E. Liepinsh and G. Otting, J. Am. Chem. Soc., 1994, 116, 96709674.

42 Q. Zou, S. M. Habermann-Rottinghaus and K. P. Murphy, Proteins: Struct., Funct., Bioinf., 1998, 31, 107-115.

43 B. J. Bennion and V. Daggett, Proc. Natl. Acad. Sci. U. S. A., 2004, 101, 6433-6438. 